\title{
Inconsistencies in the Production Process Resulting From the Employment Structure
}

\author{
Krzysztof Nowacki, Szymon Pawlak \\ Silesian University of Technology, Poland
}

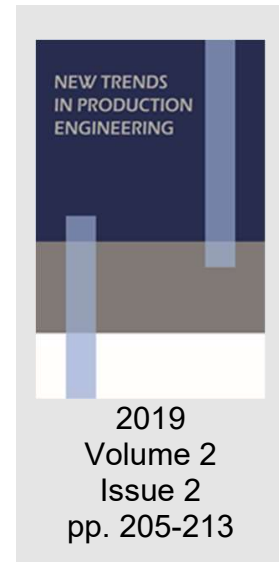

Date of submission to the Editor: 09/2019

Date of acceptance by the Editor: 11/2019

\section{PLANNING THE DURATION OF THE PRODUCTION PROCESS}

One of the basic objectives set by engineers during the planning of the production process is the correct location of all operations, treatments and other activities related to the manufacturing process underway (Burduk, et al 2019, Gawlik, et al., 2017). Properly executed stage, which is the planning of the production process, should allow to indicate the exact moment of starting and ending the production process, as well as to determine where, by whom and with the use of which devices selected operations forming part of the production process should be implemented. Production planning should be implemented based on data on, inter alia, the production capacity that the company has at the time of commencement of a given production or (in the case of long-term planning) the capacity that it will have in the future (Kotowska at. al 2017, Górecka at al. 2017, Paprocka at. al 2017, Kutschenreiter-Praszkiewicz 2016). In order to determine the basic information that allows proper planning of production is to determine the duration of production (punctuality). Defining the theoretical times takes place at the process planning stage by calculating the time of execution of individual activities performed in the framework of each production operation (Leong at al. 1990). The reason for the inability to accurately estimate the duration of production operations, especially in the case of non-automated production, is a large number of independent factors hindering the unambiguous qualification and determining the amount of possible delays. In a large number of cases, methods for estimating the duration of selected stages of the production process are determined on the basis of analytical and computational methods (such as, among others, MTM I and MTM II elementary movements) and analytical and measurement methods (e.g. timing or photo of the working day) and exploration of historical data Unfortunately, however, in a large number of cases there are large discrepancies between the theoretical times of the production process and sometimes the real time (Marlock, at al. 2017, Pawlak \& Miranowicz, 2017, Brokranz \& Landau 2012. 
The occurrence of the underestimation of the duration of the production process is particularly evident in production plants specializing in serial production of a parallel or series-parallel system. In the case of a parallel system, the element being executed immediately after the completion of a particular operation is immediately transported to another workstation, the workstation is used for further actions aimed at making the final element. The station receiving the element should be ready for immediate implementation of the given operation, Fig. 1.

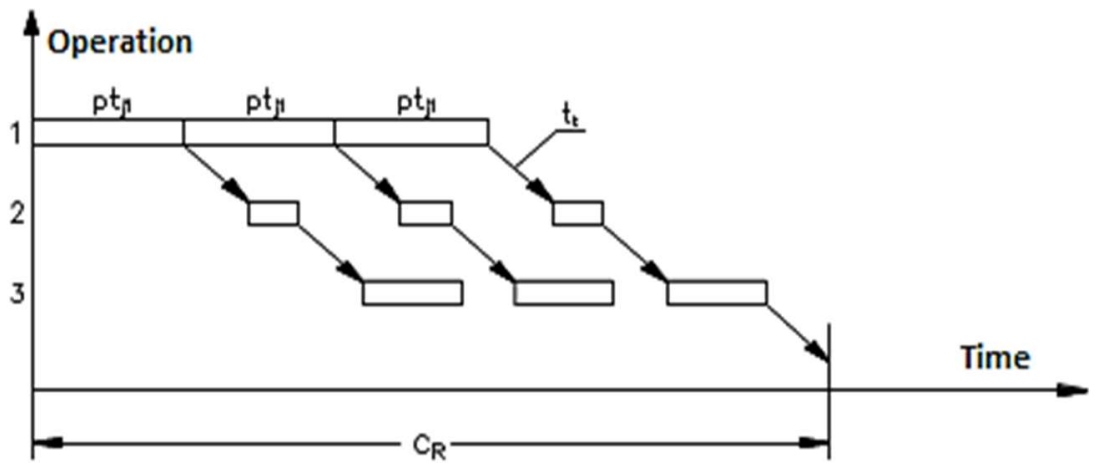

Source: (Pawlak, Nowacki 2017)

Fig. 1 Parallel system

When the duration of individual operations is equal to or is a multiple of a number of operations taking place in shorter time series, it can be concluded that the applied parallel flow implements the principle of continuity of the flow of elements. In other cases, there is a need for machine downtimes whose working rhythm is determined by the duration of the previous production task. In order to reduce losses related to downtime of particular positions, attempts should be made to align the rhythms of operation of all production units or to minimize the occurrence of time intervals arising between operations (Pająk, 2016, Lisowski \& Kozłowski 2016, Pawlak \& Nowacki 2017).

\section{Assumptions:}

$t_{j}$ - unit time of the operation, $p$ - size of the transport lot, $t_{t}$ - time of the transport operation, $\mathrm{Cr}$ - total duration of the parallel flow $\mathrm{Csr}$ - total duration of the serialparallel flow.

Serial-parallel system

The basic feature of the serial-parallel system is to run production continuously, while reducing the level of generated inter-operable stocks. For this purpose, the workplace waiting to perform the machining process does not wait for the entire batch of elements produced in the previous workplace, and starts working as soon as possible. In this case, there is a need to synchronize tasks consisting (depending on the case considered) immediately joining the job or delaying it, Fig. 2 (Pająk, 2006, Pawlak \& Nowacki, 2017).

The development of a precise schedule taking into account the location of particular operations over time is based mainly on the theoretical synchronization of their work time. A meticulously prepared schedule that allows to obtain serial-parallel flow is difficult to implement. 


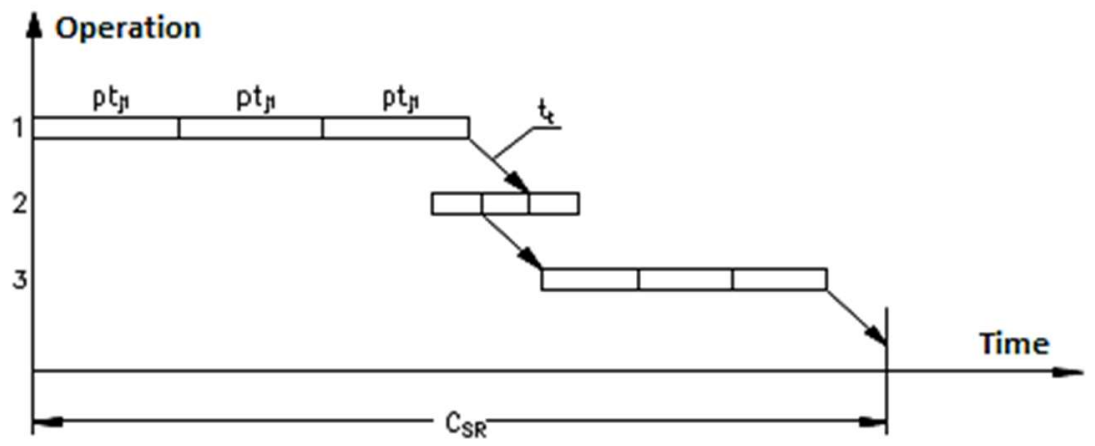

Source: (Pawlak, Nowacki 2017)

Fig. 2 Serial - parallel flow

Random events, such as: untimely delivery of materials, machine failures or mistakes made by production personnel, may result in a longer time of a given operation, which is directly related to the risk of colliding of actual tasks with events scheduled in the schedule. The lack of full synchronization of events resulting from the delay or possible inability to undertake the operation at the exact time set prevents the implementation of a properly functioning serialparallel flow.

The occurrence of time delays on any of the existing production operations carried out with a parallel or serial-parallel system determines the delay of the entire production process, the generation of intermediate stocks and the difficulty in estimating the company's production capacity. In production processes with such characteristics, identification and analysis of the reasons for underestimating the duration of the production process is one of the basic activities allowing to determine the reasons for their occurrence. The activities causing the factors determining underestimation depend, inter alia, on the type of production process, the level of complexity of production operations carried out as part of the analyzed production process, production volume, material flow organization applied between the various operations included in the process, skills and qualifications of employees and the structure of their employment.

The paper presents an analysis of the production process of the underestimation of the duration of the production process, taking into account the employment structure in the manufacturing company. The analyzes allow to determine the level of underestimation of operations of the production process depending on the form of employment (steel workers - employed under a contract of employment in the production plant, and temporary workers employed by temporary work agencies), identification of the reasons for the underestimation of individual production positions and the length of their time occurrence.

\section{ANALYSIS OF THE UNDERESTIMATION OF THE DURATION OF THE PRODUCTION PROCESS}

The production process carried out in a serial-parallel system was analyzed. The production process consists of 9 production operations marked with A-I symbols, implemented on separate production cell. The period covered by the analysis was 2 months (February and March) on three working changes. Table 1 shows 
the number of the production cell, its name and the theoretical time of the production operation, calculated using the MTM 1 method.

Table 1 The duration of production operations

\begin{tabular}{|c|c|}
\hline Designation of the production cell & Theoretical duration of operation [s] \\
\hline A & 650 \\
\hline B & 212 \\
\hline C & 200 \\
\hline D & 350 \\
\hline E & 225 \\
\hline F & 202 \\
\hline G & 340 \\
\hline H & 120 \\
\hline I & 240 \\
\hline
\end{tabular}

In order to analyze the causes of time delays occurring over time, identification of causes that underestimate the manufacturing process was taken into account, including the underside and its duration on a particular change. Table 2 shows the causes of delays in the production process, recorded during the period of time analyzed. Each delay cause has a code defined by the manufacturer.

Table 2 Causes of delays

\begin{tabular}{|c|l|}
\hline Code of the cause & \multicolumn{1}{|c|}{ Description of the cause } \\
\hline 4000 & Service (over-standard service time) \\
\hline 4002 & Start from the standstill \\
\hline 4004 & Over-standard setting time \\
\hline 4007 & Technical failure of the machine \\
\hline 4009 & The difference for service \\
\hline 4011 & Material defect \\
\hline
\end{tabular}

Table 3 The number of employees and the level of underestimation of the duration of the production process - February

February - Week 1

\begin{tabular}{|c|c|c|c|}
\hline \multirow{2}{*}{$\begin{array}{c}\text { February - Week } 1 \\
\text { Employees: } \\
\end{array}$} & \\
\hline & Permanent & Temporary & Total \\
\hline Number of employees & 156 & 68 & 224 \\
\hline Percentage of employees & $70 \%$ & $30 \%$ & \\
\hline The sum of ineffective time & 189,06 & 371,02 & 560,08 \\
\hline Percentage of ineffective time & $34 \%$ & $66 \%$ & \\
\hline \multicolumn{4}{|l|}{ February - Week 2} \\
\hline Employees: & Permanent & Temporary & Total \\
\hline Number of employees & 148 & 69 & 217 \\
\hline Percentage of employees & $68 \%$ & $32 \%$ & \\
\hline The sum of ineffective time & 165,12 & 389.1 & 554,22 \\
\hline Percentage of ineffective time & $35 \%$ & $65 \%$ & \\
\hline \multicolumn{4}{|l|}{ February - Week 3} \\
\hline Employees: & Permanent & Temporary & Total \\
\hline Number of employees & 152 & 66 & 218 \\
\hline Percentage of employees & $70 \%$ & $30 \%$ & \\
\hline The sum of ineffective time & 201,2 & 278,8 & 480 \\
\hline Percentage of ineffective time & $42 \%$ & $58 \%$ & \\
\hline \multicolumn{4}{|l|}{ February - Week 4} \\
\hline Employees: & Permanent & Temporary & Total \\
\hline Number of employees & 171 & 71 & 242 \\
\hline Percentage of employees & $71 \%$ & $29 \%$ & \\
\hline The sum of ineffective time & 191,3 & 243,7 & 435 \\
\hline Percentage of ineffective time & $44 \%$ & $56 \%$ & \\
\hline
\end{tabular}

In order to analyze the production process in terms of occurring delays causing underestimation of the production process due to the employment structure, the 
percentage share of permanent employees - employment contract for the work in the production plant and temporary workers by temporary work agencies was analyzed, taking into account the level of generated by them underestimates, Table 3, 4.

Table 4 The number of employees and the level of underestimation of the duration of the production process - March

\begin{tabular}{|c|c|c|c|}
\hline March - Week 1 & Permanent & Temporary & Total \\
\hline Employees: & 147 & 58 & 205 \\
\hline Number of employees & $72 \%$ & $28 \%$ & \\
\hline Percentage of employees & 232,2 & 322,4 & 554,6 \\
\hline The sum of ineffective time & $42 \%$ & $58 \%$ & \\
\hline Percentage of ineffective time & \multicolumn{3}{l|}{} \\
\hline March - Week 2 & Permanent & Temporary & Total \\
\hline Employees: & 174 & 66 & 240 \\
\hline Number of employees & $73 \%$ & $28 \%$ & \\
\hline Percentage of employees & 220,2 & 310,1 & 530,3 \\
\hline The sum of ineffective time & $42 \%$ & $58 \%$ & \\
\hline Percentage of ineffective time & \multicolumn{3}{|}{} \\
\hline March - Week 3 & Permanent & Temporary & Total \\
\hline Employees: & 176 & 57 & 233 \\
\hline Number of employees & $76 \%$ & $24 \%$ & \\
\hline Percentage of employees & 199,9 & 256,8 & 456,7 \\
\hline The sum of ineffective time & $44 \%$ & $56 \%$ & \\
\hline Percentage of ineffective time & \multicolumn{3}{|}{} \\
\hline March - Week 4 & Permanent & Temporary & Total \\
\hline Employees: & 132 & 38 & 170 \\
\hline Number of employees & $78 \%$ & $22 \%$ & \\
\hline Percentage of employees & 93,9 & 261,3 & 355,2 \\
\hline The sum of ineffective time & $26 \%$ & $74 \%$ & \\
\hline Percentage of ineffective time &
\end{tabular}

In the analyzed period, an average of around $28 \%$ employees employed by temporary work agencies generated around $61 \%$ underestimation. In order to present the scale of the problem regarding the occurring delays, depending on the employment structure of employees, the average delay time per employee in a given week is presented in Figures 3 and 4.

The highest average level of delays generated by temporary employees in a particular week occurred in the 4th week of March and amounted to 6.88 [h] with a lag time of only $0.71[\mathrm{~h}]$ in the case of permanent employees.

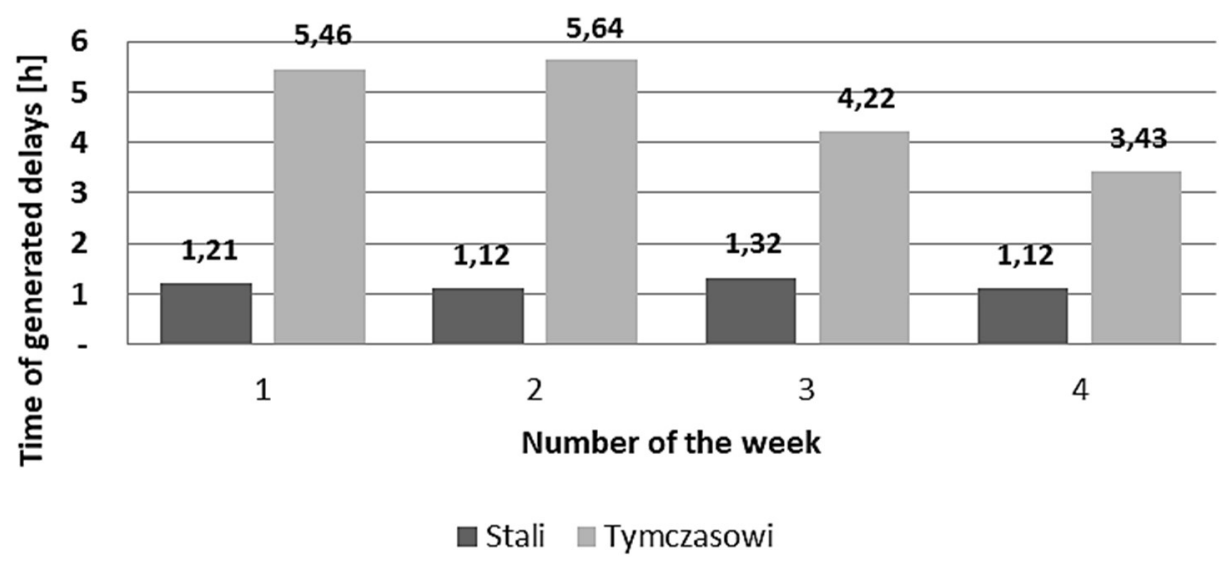

Fig. 3 Average time of delay per employee [h] - February 


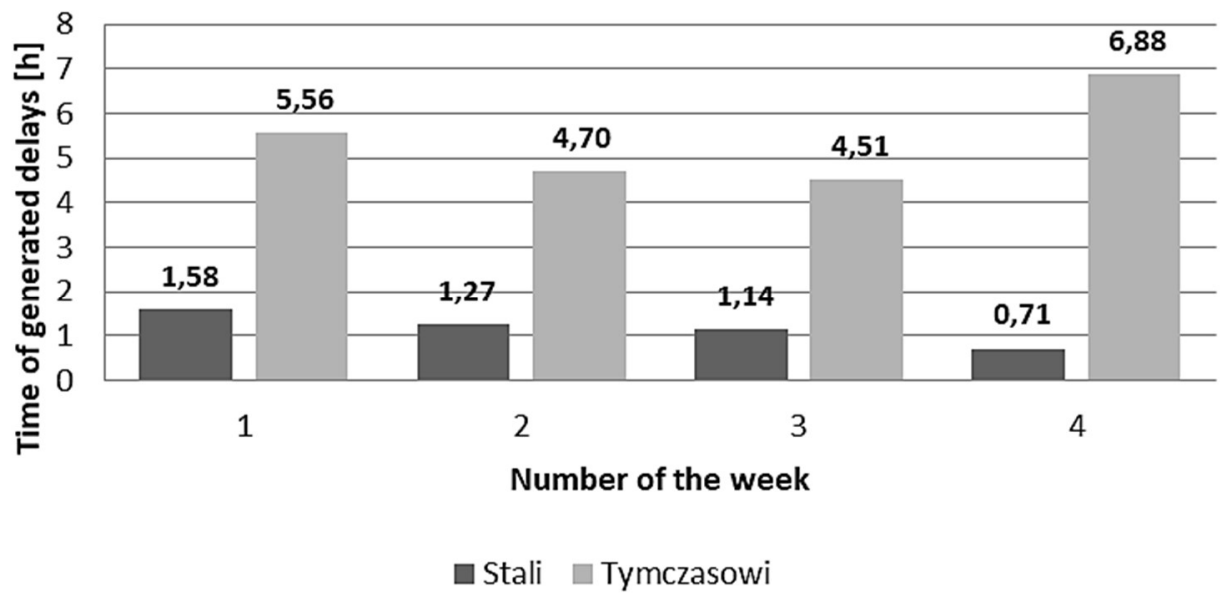

Fig. 4 Average time of delay per employee [h] - March

As a result of the analysis of the data showing the differences in the delay of the production process generated by temporary employees with respect to temporary employees, a detailed analysis of the distribution of underscore causes occurring at individual production cells was made, Table 5.

Table 5 Causes of delays on selected production cells

\begin{tabular}{|c|c|c|c|}
\hline & $\begin{array}{c}\text { Name } \\
\text { of the production cell }\end{array}$ & $\begin{array}{l}\text { The cause } \\
\text { February }\end{array}$ & $\begin{array}{l}\text { The cause } \\
\text { March }\end{array}$ \\
\hline Permanent & \multirow{2}{*}{$A$} & $4004,4007,4002$ & $4004,4007,4002$ \\
\hline Temporary & & $4004,4007,4002$ & 4004,4007 \\
\hline Permanent & \multirow{2}{*}{$B$} & 4011 & 4000,4011 \\
\hline Temporary & & $4000,4004,4011$ & $4000,4004,4011$ \\
\hline Permanent & \multirow{2}{*}{ C } & 4009 & 4008,4009 \\
\hline Temporary & & 4009,4008 & 4008,4009 \\
\hline Permanent & \multirow{2}{*}{ D } & - & 4009 \\
\hline Temporary & & $4008,4009,4011$ & 4009,4011 \\
\hline Permanent & \multirow{2}{*}{$E$} & 4011,4008 & 4008,4009 \\
\hline Temporary & & $4008,4009,4011$ & $4008,4009,4011$ \\
\hline Permanent & \multirow[b]{2}{*}{$F$} & 4000 & 4000,4004 \\
\hline Temporary & & $4000,4004,4008$ & 4000,4004 \\
\hline Permanent & \multirow{2}{*}{ G } & $4004,4007,4002$ & $4004,4007,4002$ \\
\hline Temporary & & $4002,4007,4011,4004$ & $4002,4007,4011,4004$ \\
\hline Permanent & \multirow[b]{2}{*}{$\mathrm{H}$} & - & 4009 \\
\hline $\begin{array}{l}\text { Temporary } \\
\text { employees }\end{array}$ & & 4004 & 4004,4009 \\
\hline
\end{tabular}

After the analysis, it was found that in a large number of cases, there was a greater number of reasons for delays in the case of employees hired by temporary work agencies at individual production cells. The largest disproportion in the number of occurring causes of undervaluation occurred in the production cell $B$ in the entire analyzed period, in the case of permanent employees the only occurring cause of underestimation was material defect, while in the case of temporary workers: material defect, over-standard service time, over-standard setting time.

In order to determine the level of time differences between temporary and permanent employees during the delay at individual production cells, Tables 6 and 7 were prepared, specifying the exact time of delays, all underestimation reasons occurring at the selected production cell. 
Table 6 Delays occurring at selected production cells - February

\begin{tabular}{|c|c|c|c|c|c|c|c|c|}
\hline \multicolumn{9}{|c|}{ Underestimation of the time, permanent employees - February [h] } \\
\hline \multirow{2}{*}{ Cause } & \multicolumn{8}{|c|}{ Production cell } \\
\hline & A & B & $\mathbf{C}$ & $\mathbf{D}$ & $\mathbf{F}$ & G & $\mathbf{H}$ & $\mathbf{I}$ \\
\hline 4004 & 32 & & & & & & 64 & \\
\hline 4007 & 48 & & & & & & 34 & \\
\hline 4000 & & & & & & 109 & & \\
\hline 4009 & & 118 & 142 & & & & & \\
\hline 4011 & & & & & 62 & & & \\
\hline 4002 & 12 & & & & & & 45 & \\
\hline \multicolumn{9}{|c|}{ Underestimation time, temporary employees - February [h] } \\
\hline Cause & A & B & C & D & $\mathbf{F}$ & G & $\mathbf{H}$ & $I$ \\
\hline 4004 & 67 & 21 & & & & & 58 & 35 \\
\hline 4007 & 158 & & & & & & 32 & \\
\hline 4000 & & 112 & & & & 154 & & \\
\hline 4009 & & 164 & 210 & 39 & 15 & & & \\
\hline 4011 & & & & & 81 & & 13 & \\
\hline 4002 & 86 & & & & & & 131 & \\
\hline $\begin{array}{l}\text { Ineffective time generated } \\
\text { by permanent employees }\end{array}$ & 93 & 118 & 142 & 0 & 62 & 109 & 143 & 0 \\
\hline $\begin{array}{l}\text { Ineffective time generated } \\
\text { by temporary employees }\end{array}$ & 313 & 298 & 210 & 39,2 & 97 & 154 & 234 & 35 \\
\hline
\end{tabular}

Table 7 Delays occurring on selected production cells - March Underestimation of the time, permanent employees - March [h]

\begin{tabular}{|c|c|c|c|c|c|c|c|c|}
\hline \multicolumn{9}{|c|}{ Underestimation of the time, permanent employees - March [h] } \\
\hline \multirow{2}{*}{ Cause } & \multicolumn{8}{|c|}{ Production cell } \\
\hline & $\mathbf{A}$ & B & C & $\mathbf{D}$ & $\mathbf{F}$ & G & $\mathbf{H}$ & I \\
\hline 4004 & 28 & & & & & & 32 & \\
\hline 4007 & 37 & & 28 & & & & 23 & \\
\hline 4000 & & 21 & & & & 131 & & \\
\hline 4009 & & 111 & 159 & & 78 & & & 9 \\
\hline 4011 & & & & 21 & 59 & & & \\
\hline 4002 & 10 & & & & & & 36 & \\
\hline \multicolumn{9}{|c|}{ Underestimation time, temporary employees - March [h] } \\
\hline Cause & $A$ & B & C & D & $F$ & G & H & I \\
\hline 4004 & 68 & & & & & & 46 & 10 \\
\hline 4007 & 120 & 12 & & & & & 32 & \\
\hline 4000 & & 112 & & & & 151 & & \\
\hline 4009 & 10 & 130 & 179 & 39 & 15 & 26 & & 23 \\
\hline 4011 & & & & & 81 & & 13 & \\
\hline 4002 & & & & & & & 80 & \\
\hline $\begin{array}{l}\text { Ineffective time generated } \\
\text { by permanent employees }\end{array}$ & 76 & 111 & 187,7 & 21 & 137 & 131 & 92 & 9 \\
\hline $\begin{array}{l}\text { Ineffective time generated } \\
\text { by temporary employees }\end{array}$ & 198 & 255 & 179,3 & 39 & 97 & 177 & 171 & 33 \\
\hline
\end{tabular}

As a result of the comparative analysis of inefficient time generated by permanent and temporary employees, it was found that in the verified period of time, in each of the production cells, the delay time in relation to the assumed one was larger in the case of temporary employees. In the analyzed period, the highest level of occurring delays occurred on the production nest $A$ and $B$, and the main reason for the underestimation was the "difference in service" - not meeting the time standards calculated at the planning stage of the production process.

\section{CONCULSION}

The complexity of the production planning process is caused by a huge number of factors seemingly independent, impeding precise definition of the duration of individual operations, and determining the actual production capacity of the 
company. Statistical analysis of data obtained on the basis of continuous control of the manufacturing process allows in many cases identification of key reasons that cause a high level of underestimation. In the described case, the underestimation of the duration of the production process generated by production workers (temporary and permanent) was subject to analysis.

The calculations carried out in a given time interval clearly indicate a large time discrepancy in the case of temporary employees, causing numerous delays in the production process. The occurring undervaluation causes numerous downtimes and makes it impossible to determine the actual production capacity of the company. Obtained results may lead to removal of reasons for delays or the introduction of corrective actions aimed at reducing the impact of their impact on the duration of the production process.

\section{REFERENCES}

Bokranz, R. and Landau, K. (2012) Handbuch Industroal Engineering: Produktivitatsmanagement mit MTM. Band 1: Konzept, 2. Auflage. SchafferPoeschel, Stuttgart.

Bożejko W., Grymin R and Pempera J., (2018). Scheduling and Routing Algorithms for Rail Freight Transportation, Procedia Engineering, pp. 206-212.

Bożejko W., Pempera J and Smutnicki A. (2008). Parallel Single-Thread Strategies in Schedu-ling, in Rutkowski L., Tadeusiewicz R., Zadeh L.A and Zurada J.M., Artificial Intelligence and Soft Computing, ICAISC 2008, Lecture Notes in Computer Science, 5097, Springer, Berlin, Heidelberg, pp. 995-1006.

Burduk, A., Musiał, K.,Kochańska, J., Górnicka D and Stetsenko A. (2019). Tabu search and genetic algorithm for production process scheduling problem, Scientific Journal of Logistics, 2019, pp 181-189.

Chen L., Jansen K., and Zhang G. (2018). On the optimality of exact and approximation algorithms for scheduling problems, Journal of Computer and System Sciences, pp. 1-32

Gawlik, J., Plichta, J. and Świć, A. (2013). Procesy produkcyjne, Warszawa, Polskie Wydawnictwo Ekonomiczne.

Górnicka D., Markowski M. and Burduk A. (2018). Optimization of production organization in a packaging company by ant colony algorithm, in Burduk A., Mazurkiewicz D. (Ed.), ISPEM 2017, AISC, 637, Springer, pp. 336-346,

Grajek M. and Zmuda-Trzebiatowski P. (2014). A heuristic approach to the daily delivery scheduling problem. Case study: alcohol products delivery scheduling within intracommunity trade legislation, Logforum, pp. 163-173.

Imai, M. (2006). Gemba Kaizen, Warszawa, MT Biznes.

Kotowska, J., Markowski, M. and Burduk, A., 2018. Optimization of the Supply of Components for Mass Production with the Use of the Ant Colony Algorithm, in Burduk A., Mazurkiewicz D. (Ed.), ISPEM 2017, AISC, 637, Springer, Cham, 347357.

Kowalska K., Sikora L and Hadaś Ł. (2017). Analiza zakłóceń procesu produkcyjnego na wybranym przykładzie, Zeszyt Naukowy Politechniki Poznańskiej, Organizacja i Zarządzanie, Poznań, pp. 145-158.

Kumanan S. and Jegan Jose, G and Raja, K. (2006). Multi-project scheduling using an heuristic and a genetic algorithm, pp. 360-366.

Kutschenreiter-Praszkiewicz, I. (2016). Wybrane zagadnienia planowania procesu produkcyjnego. In: Innowacje w Zarządzaniu i Inżynierii Produkcji, Opole.

Leong, G.K., Snyder, D.L and Ward, P.T. (1990) Research in the process and content of manufacturing strategy, Omega, pp. 114. 
Małysa, T, Nowacki, K and Lis, T. (2017). The correlation between structure of employment and accidents at work in metallurgical enterprises. In: METAL 2017: 26th International Conference on Metallurgy and Materials, pp. 2244-2249.

Morlock, F., Kreggenfald N., Louw L., Kreimeier D., Kuhlenkotter B. (2017) Teaching Methods-Time Measurment (MTM) for Workplace Design in Learning Factories, $7^{\text {th }}$ Conference on Learning Factories, CLF 2017, pp 370-375.

Paprocka I., Gwiazda A and Baczkowicz M. (2017). Scheduling of an assembly process of a chosen technical mean using the critical chain approach, MATEC Web of Conferences.

Pawlak, Sz. and Miranowicz, A. (2017). Wpływ czynników techniczno-ludzkich na plan procesu produkcji. Częstochowa.

Wojakowski, P. (2011). Metoda szacowania długości okresu planowania z zastosowaniem techniki eksploracji danych. In: Czasopismo Techniczne, Kraków, Wydawnictwo Politechniki Krakowskiej, pp. 127-146.

Shishido H.Y., Estrella J.C., Toledo C.F.M. and Arantes M.S. (2018). Genetic-based algorithms applied to a workflow scheduling algorithm with security and deadline constraints in clouds, Computers \& Electrical Engineering, pp. 378-394.

\begin{abstract}
.
Underestimating the duration of the production process is one of the basic factors determining the occurrence of delays in the duration of individual operations included in the production process. Occurrence of underestimation of production time brings many negative effects, which include, among others: underestimation of the company's production capacity, accumulation of intermediate stocks, impeded planning of the production process (scheduling of the production process) and increase of production costs. The problem of erroneous estimation of the duration of the production process is most often found in production plants specializing in serial or mass production, implemented in a parallel or series-parallel system. The basic causes that underestimate the duration of the production process include errors in production scheduling, incorrect determination of durations of individual operations carried out as part of the analyzed production process, complexity of production operations and employment structure. The occurrence of delays in the production process can also be affected by accident events that generate underestimation and costs for the enterprise (including social and economic costs). In many cases, many algorithms are used to reduce underestimation and optimization and scheduling of the entire production process. The publication presents an analysis of the production process in which the duration of the production process is underestimated, taking into account the employment structure in the manufacturing company. The analyzes allow to determine the level of underestimation of operations of the production process depending on the form of employment (steel workers employed under a contract of employment in the production plant, and temporary workers employed by temporary work agencies), identification of the reasons for the underestimation of individual production positions and the length of their time occurrence.
\end{abstract}

Keywords: production, production planning, underestimation 